\title{
3D ARTIFICIAL POLYMERIC SCAFFOLDS FOR STEM CELL GROWTH FABRICATED BY FEMTOSECOND LASER
}

\author{
M. Malinauskas a, P. Danilevičius ${ }^{\text {a }}$, D. Baltriukiené ${ }^{\mathrm{b}}$, M. Rutkauskas ${ }^{\mathrm{a}}$,

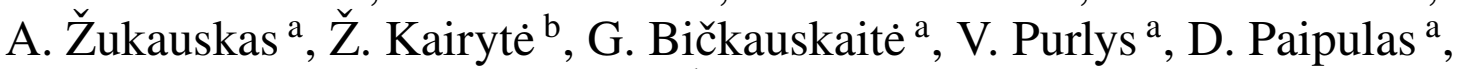 \\ V. Bukelskiené ${ }^{\mathrm{b}}$, and R. Gadonas ${ }^{\mathrm{a}}$ \\ ${ }^{a}$ Department of Quantum Electronics and Laser Research Centre, Vilnius University, Sauletekio 10, LT-10223 Vilnius, \\ Lithuania \\ E-mail: mangirdas.malinauskas@ff.vu.lt \\ ${ }^{\mathrm{b}}$ Vivarium, Institute of Biochemistry, Mokslininku 12, LT-08662 Vilnius, Lithuania
}

Received 16 October 2009; revised 18 March 2010; accepted 19 March 2010

\begin{abstract}
Femtosecond Laser Induced Polymerization is an attractive direct writing technique for rapid three-dimensional (3D) micro and nanofabrication in diverse applications. Recently, it has been successfully applied for 3D scaffold fabrication required in biomedicine applications. However, there are still a lot of investigations to be done before it can be used for practical applications in tissue engineering or regenerative medicine. In this work, experimental results on production of artificial polymeric scaffolds for stem cell growth are presented. Parameters (average laser power, sample scanning speed, and developing conditions) for microfabrication in biocompatible photopolymers AKRE (AKRE37) and ORMOSIL (SZ2080) are experimentally determined. 3D custom form and size artificial scaffolds were successfully microfabricated. Adult stem cell growth on them was investigated in order to test their biocompatibility. The results of myogenic stem cell culture expansion were compared to the control growth of the same cells on the scaffolds manufactured out of commonly used biocompatible photopolymers ORMOCER (Ormocore b59) and Poly-Ethylen Glycol Di-Acrylate (PEG-DA-258). Preliminary results show FLIP technique to have potential in fabrication of artificial 3D polymeric scaffolds for cell proliferation experiments. These are the first steps in transferring FLIP fabrication method from laboratory tests to flexible manufacturing of individual scaffolds out of biocompatible and biodegradable polymers.
\end{abstract}

Keywords: femtosecond laser, two-photon polymerization, 3D micro-fabrication, biocompatible photopolymers, artificial scaffolds

PACS: 82.30.Cf, 89.20.Bb, 87.17.Rt

\section{Introduction}

Currently, Femtosecond Laser Induced Polymerization (FLIP) technology is being applied in tissue engineering [1]. Diseases and injuries create a high demand of artificial tissues which could be transplanted into living organism. One of the research fields of growing interest is tissue engineering and production of artificial scaffolds on which cells could controllably grow and form tissues [2]. The need of manipulating the scaffold structure is obvious in seeking to grow cells in 3D space [3]. FLIP satisfies the resolution and fabrication requirements in terms of 3D microobject formation. Biocompatible photopolymers are used for production of complex form scaffolds, which not only act as frames for growing cells, but could determine the shape of regenerating organ [4]. It is known that by changing poly- mer's mechanical and chemical properties the proliferation of cells on them can be selectively controlled $[3,5]$.

Laser fabrication technologies of various microobjects for functional devices were developed rapidly during the past decades [6]. One of these constantly growing technologies - laser induced photopolymerization - got a lot of attention because its simplicity and high throughput. The photopolymerization patterning is based on selectively exposing photosensitive material to UV light [7]. Irreversible chain reaction induced in the exposed monomer volume forms polymers from which the microobjects are built [8]. Microstereolithography systems are already commercially available [9]. However, this method can be used for fabrication of two-dimensional (2D) objects, and formation of threedimensional (3D) structures becomes long and complex [10]. 
Alternative and more sophisticated FLIP technique, based on nonlinear multi-photon absorption, has gained a great interest due to the possibility to fabricate 3D micro and nanoobjects [11]. Due to quadratic dependence on light intensity, polymerization reaction is induced in tiny focused volume of monomer that allows formation of microstructures in 3D space [12]. It has been already recognized as an effective method for fabricating 3D optoelectronic devices, photonic crystals, micromechanical components, etc. [13].

The regenerative medicine involves a multidisciplinary effort establishing measures to stop the problems impending human health or to repair already diseased tissues and organs. It combines the two developed in parallel, but inter-related biomedical research directions - cell therapy and tissue engineering [14]. Cell therapy is an approach of introducing new healthy cells into a damaged tissue in order to treat a disease. A variety of cell types have been used for cell therapy. The most promising are embryonic stem cells; they can differentiate into any type of cell. Non-embryonic stem cells, also known as incompletely differentiated, or adult stem cells are just multipotent; their potential to differentiate into different cell types seems to be more limited. Other direction of regenerative medicine is tissue engineering. Tissue engineering is an interdisciplinary field that applies the principles of engineering and life sciences towards the design and construction of functional tissues intended for the maintenance, regeneration, or replacement of multifunctional organs. The most promising strategy for tissue engineering is growing of autologous adult stem cells in a 3D environment that aims to mimic the natural tissue as closely as possible [15]. Later such artificial tissues or organs could be transplanted to the organism [16]. There are many data that both regenerative medicine directions offer many promising new technologies and products which should help people suffering from injuries and some diseases (diabetes, bone and cartilage damage, vascular or other) [17]. Also, tissue engineering is currently developed in several directions. One of them is based on using biological tissue without the cells. Another method of the tissue construction is based on the artificial tissue engineering. Such tissue manufacturing technologies may be developed in two directions as well. The first of them is the creation of a synthetic matrix, which would be transplanted into the organism and stand as a basis for new biological tissues, formed through the body's natural vital forces. The second one is construction of special artificial scaffolds for cell growing in vitro. When the cells would be expanded on the scaffold, it could be transplanted into the pathological lesion in the organism [18]. The successful creation of artificial biological tissues is inseparable from the understanding of the physiological, cellular, and molecular mechanisms of individual tissues or organs in the living organism as well as modelling them in the artificial system in vitro. Recognition of the vital processes in vivo and their successful simulation in vitro is the main reference point for the successful construction of biological tissue with optimal composition and structure, selection of cell types, growth factors, and their concentration [19].

The aim of this experimental work was to investigate the feasibility and optimize the fabrication parameters for 3D artificial polymeric scaffold production by means of FLIP and to test AKRE37 and SZ2080 material and structure biocompatibility by growing cells on them.

\section{Experimental part}

\subsection{Fabrication of the scaffolds}

Scheme of FLIP system is shown in Fig. 1(a). In our experiment femtosecond Ti:Sapphire (Super Spitfire, Spectra Physics) laser was used as an irradiation source with average output power of $500 \mathrm{~mW}$ operating at $800 \mathrm{~nm}$ central wavelength and $80 \mathrm{fs}$ pulse duration at $80 \mathrm{MHz}$ pulse repetition rate. The fully automated system consists of laser irradiation power controlling devices, collimating and focusing optics, CMOS camera for online monitoring of the fabrication process, piezo stages for precise sample positioning, and computer for the automated control of the whole system via "3D Poli" software. The sample is moved relatively to the focused laser beam thus tracing the contours of the desired structure, which can be imported directly from Computer Aided Design (CAD) file. The more detailed description of the FLIP system is provided in reference paper [20]. Easy change of objective lenses enables one to scale up or scale down the fabrication resolution versus fabrication throughput [21]. In these experiments $20 \times \mathrm{NA}=0.5$ and $100 \times \mathrm{NA}=1.4$ microscope objectives were applied.

Four different negative tone photoresins for 3D scaffold structuring were used. AKRE (an acrylate based custom made photopolymer AKRE37 consisting of tris(2-hydroxy ethyl)isocyanurate triacrylate and 4,4'bis(di-methylamino)benzophenone [22]) and ORMOSIL (hybrid organic-inorganic SZ2080 material, FORTH [23]) were tested as candidate materials for artificial scaffold fabrication. They are already recognized to be 


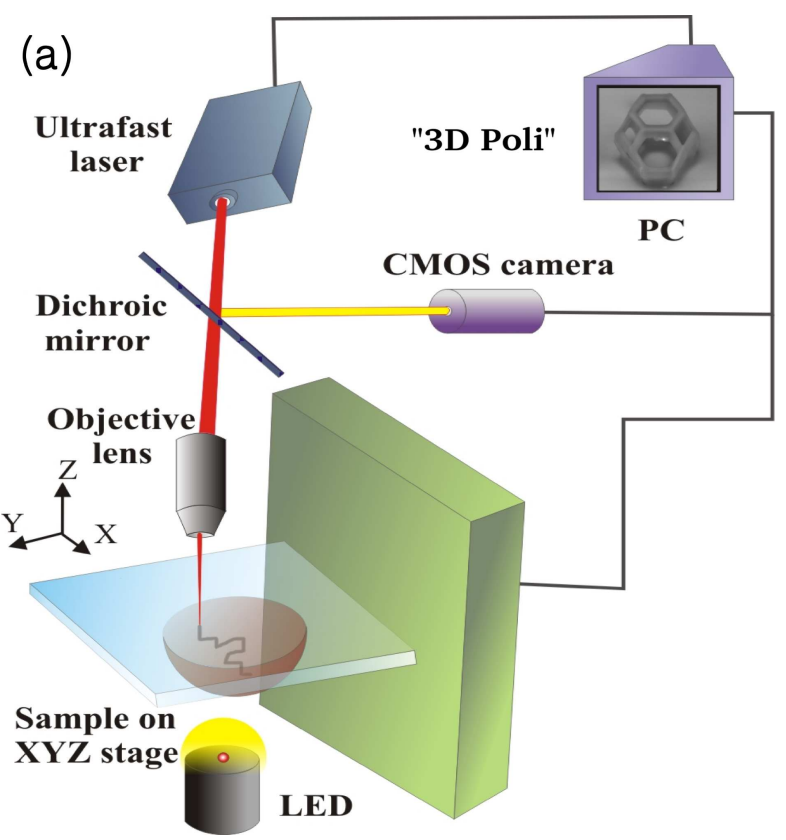

(b)

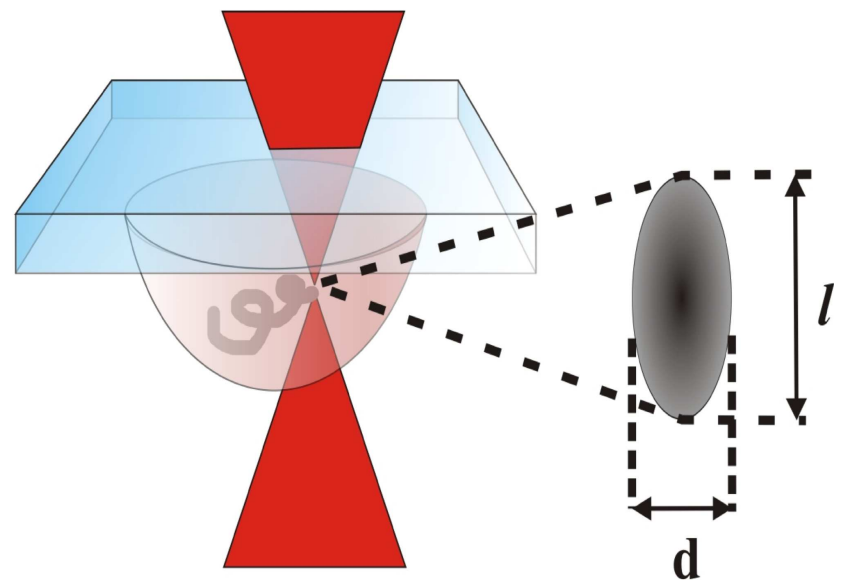

Fig. 1. (a) FLIP system. (b) Pin-point direct writing. Photopolymer is solidified following the trace of the focused femtosecond laser beam. Smallest structural element voxel is elongated along optical axis, achievable resolution can reach less than $1 \mu \mathrm{m}$ in most of the commonly used photopolymers.

excellent for 3D micro and nanostructuring. ORMOCER (Ormocore b59, Microresist GmbH) and biodegradable PEG-DA (Poly-Ethylen Glycol Di-Acrylate Mn 258, Sigma-Aldrich Co.) are known to be biocompatible materials and have been used as the reference photopolymers for determining the biocompatibility from the cell growth $[24,25]$.

\subsection{Cell isolation and expansion}

Primary stem cell culture derived from adult rabbit muscle was applied for engineering of polymericorigin artificial tissue [26]. Isolated myogenic stem cells were grown in the polystyrene tissue culture plates containing Iscove's modified Dullbeco's (Gibco) growth medium supplemented with $10 \%$ of fetal calf serum (Gibco), penicillin $(100 \mathrm{U} / \mathrm{ml})$, and streptomycin $(100 \mu \mathrm{g} / \mathrm{ml})$. Cells were maintained at $37^{\circ} \mathrm{C}$ in humidified atmosphere with $5 \% \mathrm{CO}_{2}$ and passaged twice a week detaching cells from the plate by 0.25 (w/v) trypsin/EDTA solution (Gibco). The fabricated scaffolds were sterilized in $70^{\circ}$ ethanol (for $48 \mathrm{~h}$ ) and after that by UV radiation (15 min for each side).

The cells were stained with $10 \mu \mathrm{g} / \mathrm{ml}$ diamidino2-phenylindole (DAPI) prior to the inoculation to the scaffold-containing wells. DAPI is the classic blue fluorescent probe for viable cells that fluoresces brightly when it is bound to DNA. In the standard culture medium, DAPI stained myogenic stem cells at density of 60,000 per $\mathrm{ml}$ were inoculated into each plate well containing FLIP engineered scaffolds from AKRE37, SZ2080, PEG-DA-258, as well as Ormocore b59. After $72 \mathrm{~h}$ cultivation the intensity of stem cell growth was assessed microscopically.

\section{Results}

\subsection{Resolution measurement}

Suspended bridges were fabricated willing to identify the optimal fabrication parameters, like achievable fabrication resolution and scanning speed $v$ for different objectives [22,27]. To estimate possible width (lateral resolution or voxel diameter) and height (axial resolution or voxel height) of one scan fabricated wall, the average laser power was kept constant. Resolution dependence on scanning speed was measured from SEM (Scanning Electron Microscope, HITACHI TM-1000) micrographs of these structures. According to Rayleigh model focal spot size is limited by the diffraction and is expressed as

$$
\begin{aligned}
& d=\frac{1.22 \lambda}{\mathrm{NA}}, \\
& l=\frac{2 \lambda n}{\mathrm{NA}^{2}},
\end{aligned}
$$

where $d$ and $l$ are lateral and longitudinal dimensions of the diffraction limited spot, $\lambda$ is exposure wavelength, $\mathrm{NA}$ is numerical aperture, and $n$ is refractive index 

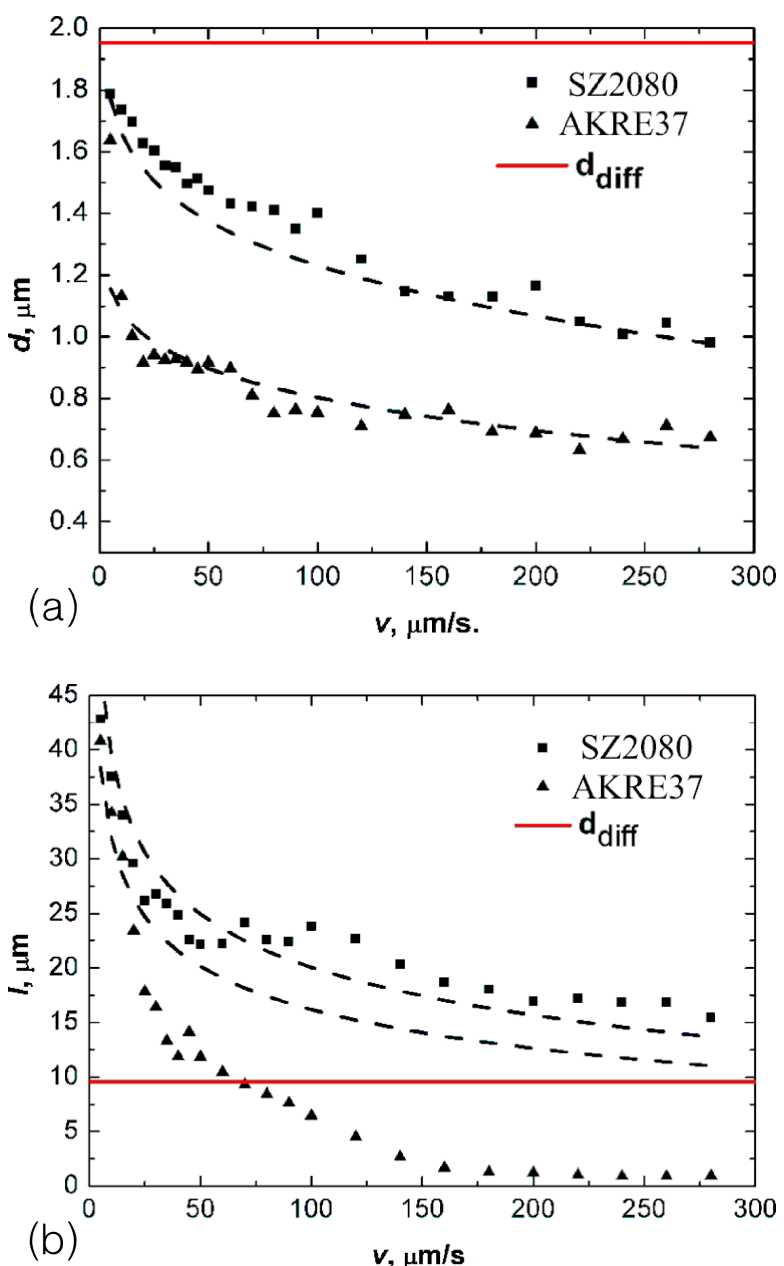

Fig. 2. Fabrication resolution dependence on sample translation speed $(v)$ using $20 \times \mathrm{NA}=0.5$ objective: (a) lateral resolution $d$, (b) longitudinal resolution $l$. Continuous line marks diffraction limit calculated using Eqs. (1) and (2), dashed lines are theoretically estimated results using Eqs. (3) and (4), assuming that $n=1.5$. Dots are measured from SEM micrographs. Excess above the diffraction limit everywhere in (a) is due to voxels having elliptical shape and being thinner at the edges, where they were measured, comparing to their maximum thickness at the waist pertaining to the diffraction limit. Disagreement in (b) of the estimated and measured longitudinal AKRE37 resolutions is due to the material shrinkage after development. (Resolution obtained with $100 \times \mathrm{NA}=1.4$ objective has been reported previously [20].)

of the sample material [28]. Using these equations diffraction limit was calculated and shown in Fig. 2. It was observed that resolution of the fabricated structures exceeded diffraction limit when appropriate parameters were chosen (laser power $P$ or scanning speed $v$ corresponding to shorter exposure at certain points) and could be defined using these equations [29]:

$$
d=\frac{\lambda}{\mathrm{NA}} \sqrt{\ln \frac{I_{0}^{2} t \beta \tau \nu}{I_{\mathrm{th}}}},
$$

$$
l=\frac{2 z_{\mathrm{R}}}{n} \sqrt{\exp \left[\frac{1}{2}\left(\frac{d \mathrm{NA}}{\lambda}\right)^{2}\right]-1} .
$$

Here, $I$ is intensity in the vicinity of focus, $t$ is exposure time, $\beta$ is experimentally derived constant pertaining to the photosensitive material response, $\tau$ and $\nu$ are laser pulse duration and repetition rate, $I_{\text {th }}$ is the intensity of polymerization threshold, $z_{\mathrm{R}}$ is Rayleigh range. Using Eqs. (3) and (4) theoretically calculated graphs and experimentally measured structuring resolution values are shown in Fig. 2.

\subsection{Fabrication of $3 D$ artificial scaffolds}

For fabrication of 3D artificial scaffolds designed for tissue engineering, AKRE37 and SZ2080 photosensitive materials, known for their good micro and nanostructuring properties, were chosen. While producing these objects, the walls of the scaffolds were formed by several parallel scans in order to increase the total exposure dose resulting in higher monomer-to-polymer conversion. As a consequence, such $3 \mathrm{D}$ objects are more tough and resistant to deformation or collapse during developing process [30-32]. Examples of fabricated 3D structures are shown in Fig. 3(a,b). Such structures could be promising artificial scaffolds for cell proliferation in $3 \mathrm{D}$ exhibiting high mechanical strength as they are made of spatial figures - truncahedrons (TRUNCAted octaHEDRON), sized $120 \times 120 \times 55 \mu \mathrm{m}^{3}$. Easy scaling ability using FLIP is demonstrated in Fig. 3(c). Single truncahedrons and more complex structures of different size could be produced within the same technological approach [21]. The pore size of the scaffold has to be about twice as big as the size of a single cell, and for mammals it would correspond to tens of micrometres [33]. Precise control of pore sizes, their homogeneity and interconnection is believed to be beneficial for cell proliferation [34]. Also, scaffold stiffness and biodegradability will depend on inner architecture and filling factor $\left(V_{\text {material }} / V_{\text {scaffold }}\right)$ [35].

\subsection{Cell-based tissue engineering}

The technique that can be used to replace damaged organ or tissue involves growing the patient's own cells on a scaffold to form a tissue-engineered medical product. The success of engineered artificial tissue depends on many parameters. Most important of them are biocompatibility of the material and the architecture of the scaffold. It was demonstrated that the shape of the scaffold or mechanotransduction plays an important role in 


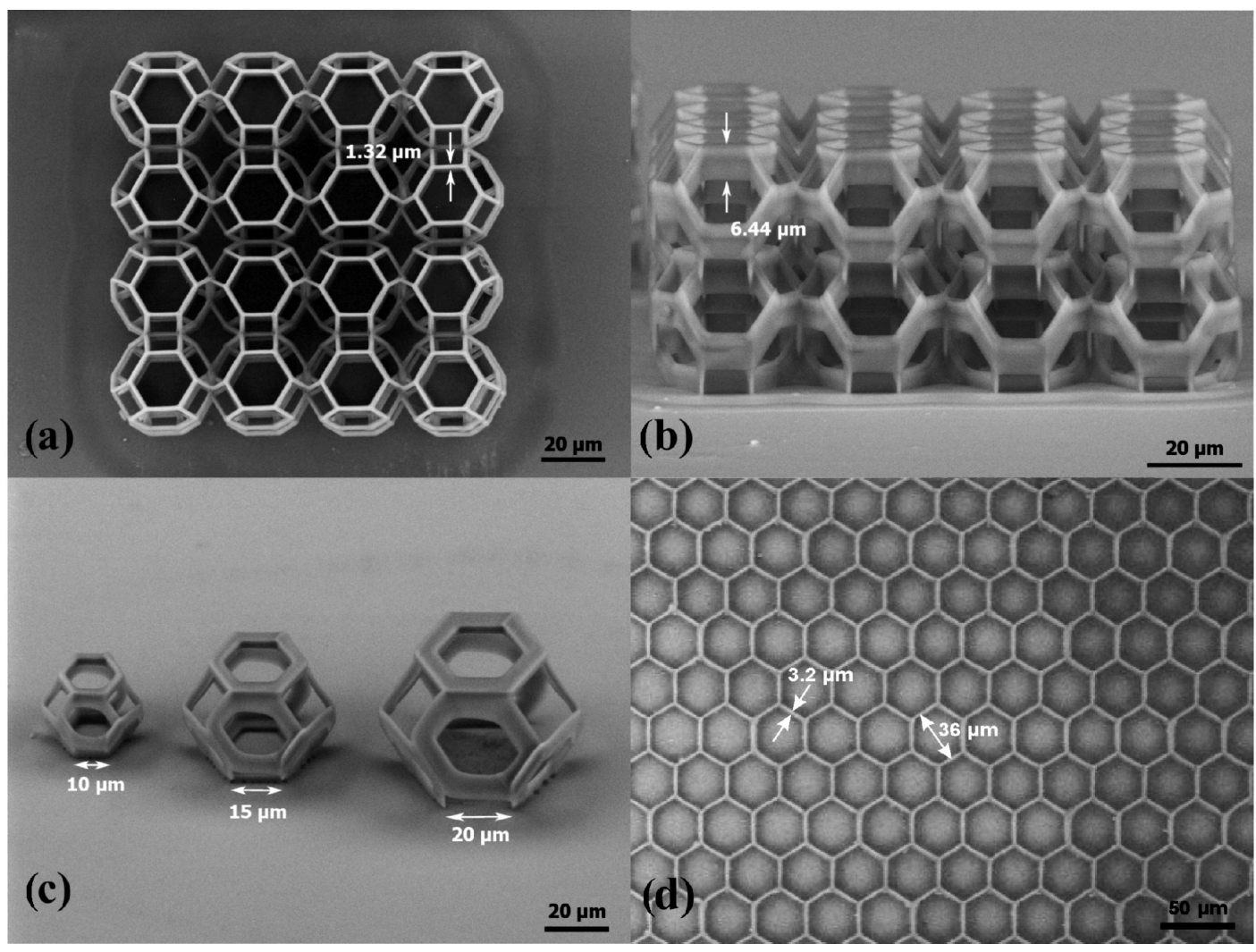

Fig. 3. SEM micrographs of 3D artificial scaffolds fabricated out of SZ2080. (a, b) Microstructures formed out of truncahedrons, (c) shows differently scaled single truncahedrons fabricated within the same procedure. Objective lens $100 \times \mathrm{NA}=1.40$ was used to fabricate these microobjects. (d) Honeycomb scaffold fabricated with $20 \times \mathrm{NA}=0.5$ objective lens. The volume and area of the pores are: $(\mathrm{a}, \mathrm{b}) 11300 \mu \mathrm{m}^{3}$; (c), from left to right, 11300,38200 , and $90500 \mu \mathrm{m}^{3}$; (d) $1890 \mu \mathrm{m}^{2}$.

growth, apoptosis, differentiation, and motility for the adhesion depended cells [36].

Biocompatibility of the scaffold as well as quality of artificial tissue can be assessed in vitro by the imaging of the nuclei of scaffold-housed cells. The nucleus of living and proliferating cell looks like unbroken relatively big membrane-bound organelle. In all our fabricated micropatterns, we can see sufficient number of blue DAPI-stained live cell nucleuses which demonstrate biocompatibility of the tested materials. The proportions of the nuclei as well as whole cell size are comparable to the pore size (Fig. 4). As the majority of mammalian cell types are anchorage-dependent and will die if no cell-adhesion substrate is available, biomaterials must provide a sufficient cell-adhesion substrate that could deliver cells to specific sites in the body with high loading efficiency [17]. Since cell fate in the scaffold depends upon the transmembrane signaling which in turn depends upon the cell-cell, cell-scaffold, and cell-growth factors interactions, qualitative studies of newly engineered scaffolds will be continued and extended in the future.

The scaffold provides a temporary housing and ap- propriate environment for the cells, therefore, it must provide an environment in which cell proliferation, migration, and differentiation can occur, thus forming functional tissue. The results of our prolonged studies (data not provided here) proved the presumption about suitability of tested scaffolds for engineering of viable tissue. The design of porous scaffold presented in this study imitates physiological situation of the cells in the tissue. Cell growth and function of the tissue is controlled by soluble proteins - growth factors, hormones, and cytokines. In our case, such components have an opportunity to penetrate porous scaffolds and reach the cells. Furthermore, cell environment governs other phenomenon - cell migration, which is very important for angiogenesis in artificial tissue [37]. Therefore, scaffolds for artificial tissue must correspond to many needs.

So, according to our data, all tested scaffolds engineered from acrylate based AKRE37 and hybrid organic-inorganic SZ2080 as well as Ormocore b59 and biodegradable PEG-DA-258 photopolymers were biocompatible and thus can be characterized as being suitable for artificial tissue engineering. This form and 


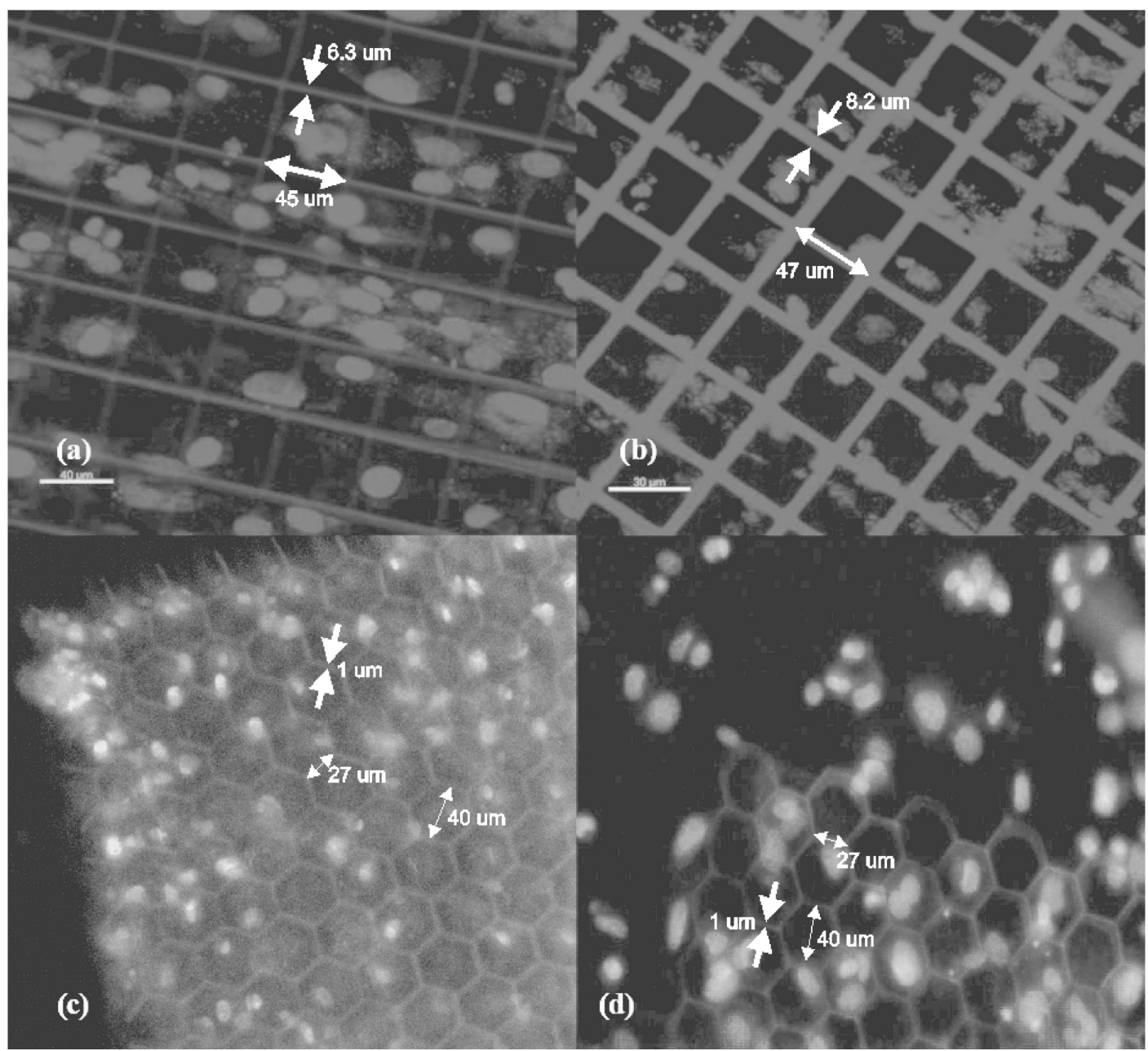

Fig. 4. Fluorescence microscope images of adult rabbit myogenic stem cells in vitro (highlighted DAPI stained nucleuses having size of $\sim 10 \mu \mathrm{m}$ and invisible cell body) expanded in the 2D artificial scaffolds fabricated out of (a) AKRE37, (b) SZ2080, (c) Ormocore b59, and (d) PEG-DA-258; cell density in all scaffolds is comparable, therefore their suitability in artificial tissue engineering applications can be judged. The pore sizes are: (a) $2025 \mu \mathrm{m}^{2}$, (b) $2200 \mu \mathrm{m}^{2}$, (c, d) $1890 \mu \mathrm{m}^{2}$.

size of microporosity 3D structures can act as cellular scaffolds for tissue engineering with tunable or increased functionalities.

\section{Conclusions}

In conclusion, microstructures fabricated out of AKRE37 and SZ2080 photopolymers shows FLIP as a potential tool for fabrication of true 3D polymeric artificial scaffolds for biomedical applications. These microstructured scaffolds are interesting for the stem cell growth and behaviour experiments (migration and localization) as well as for regenerative medicine, in the future. Obtained cell growth results show that the biocompatibility of these materials is comparable to the ones which are commonly used for biomedicine applications, such as Ormocore b59 and PEG-DA-258. Artificial polymer scaffolds can be flexibly created for every individual patient, having required geometrical, mechanical, and chemical properties. The use of such polymer scaffolds and expansion of autologous stem cells makes it possible to prepare artificial tissue tailored for each individual. This study is the first step on the way for rapidly manufacturing templates needed for tissue engineering out of AKRE37 and SZ2080 materials. Further investigations in vivo are to be done in order to better understand tissue-material interaction.

\section{Acknowledgements}

This work was supported by the Lithuanian State Science and Studies Foundation Grants B09/08 (Laser Micro-Processing with High Repetition Femtosecond Pulses) and B-07041 (Development of the Models to Regenerate Heart Structures Employing Stem and Specialized Cells and Biological Tissues). We gratefully 
acknowledge A. Gaidukevičiūtė and M. Farsari (Foundation of Research and Technology Hellas, bmm@iesl.forth.gr) for providing zirconium containing sol-gel hybrid photosensitive material SZ2080. Finally, we would like to thank Sartomer Company, Inc. for providing SR368 material for the preparation of custom made AKRE37 photopolymer.

\section{References}

[1] F. Claeyssens, E.A. Hasan, A. Gaidukevičiūtè, D.S. Achilleos, A. Ranella, C. Reinhardt, A. Ovsianikov, X. Shizhou, C. Fotakis, M. Vamvakaki, B.N. Chichkov, and M. Farsari, Three-dimensional biodegradable structures fabricated by two-photon polymerization, Langmuir 25(5), 3219-3223 (2009).

[2] S. Schlie, A. Ngezahayo, A. Ovsianikov, T. Fabian, H.A. Kolb, H. Haferkamp, and B.N. Chichkov, Threedimensional cell growth on structures fabricated from ORMOCER $®$ by two-photon polymerization technique, J. Biomater. Appl. 22, 275-287 (2007).

[3] E. Cukierman, R. Pankov, D.R. Stevens, and K.M. Yamada, Taking cell-matrix adhesions to the third dimension, Science 294(5547), 1708-1712 (2001).

[4] P. Tayalia, C.R. Mendonca, T. Baldacchini, D.J. Mooney, and E. Mazur, 3D Cell-migration studies using two-photon engineered polymer scaffolds, Adv. Mater. 20, 4494-4498 (2008).

[5] A. Ovsianikov, B.N. Chichkov, M. Malinauskas, S. Schlie, A. Ngezahayo, S. Gittard, and R. Narayan, Two-photon polymerization of Poly(ethylene glycol) materials for biomedical applications [submited to Adv. Mater.].

[6] 3D Laser Microfabrication, Principles and Applications, eds. H. Misawa and S. Juodkazis, 1st ed. (WileyVCH, Weinheim, 2006).

[7] C. Decker, Laser-induced polymerization, in: Materials for Microlithography, ACS Symp. Ser. 266, 207223 (1985).

[8] I.H. Lee and D.-W. Cho, Micro-stereolithography photopolymer solidification patterns for various laser beam exposure conditions, Int. J. Adv. Manuf. Technol. 22, 410-416 (2003).

[9] V.K. Varadan, X. Jiang, and V.V. Varadan, Microstereolithography and other Fabrication Techniques for 3D MEMS, 1st ed. (Wiley, New York, 2001).

[10] J. Stampfl, S. Baudis, C. Heller, R. Liska, A. Neumeister, R. Kling, A. Ostendorf, and M. Spitzbart, Photopolymers with tunable mechanical properties processed by laser-based high-resolution stereolithography, J. Micromech. Microeng. 18, 125014 (2008).

[11] H.-B. Sun and S. Kawata, Two-photon laser precision microfabrication and its applications to micro-nano devices and systems, J. Lightwave Technol. 21, 624-633 (2003).
[12] S.H. Park, T.W. Lim, D.Y. Yang, R.H. Kim, and K.S. Lee, Improvement of spatial resolution in nanostereolithography using radical quencher, Macromol. Res. 14(5), 559-564 (2006).

[13] S. Maruo and J. Fourkas, Recent progress in multiphoton microfabrication, Laser \& Photon. Rev. 2(1-2), 100-111 (2008).

[14] P.V. Guillot, W. Cui, N.M. Fisk, and D.J. Polak, Cell differentiation and expansion for clinical applications of tissue engineering, J. Cell. Mol. Med. 11(5), 935944 (2007).

[15] C. Boura, S. Muller, D. Vautier, D. Dumas, P. Schaaf, J. Claude Voegel, J. Francois Stoltz, and P. Menu, Endothelial cell-interactions with polyelectrolyte multilayer films, Biomater. 26(22), 4568-4575 (2005).

[16] M.N. Rahaman and J.J. Mao. Stem cell-based composite tissue constructs for regenerative medicine, Biotechnol. Bioeng. 91(3), 261-284 (2005).

[17] A. Atala, Engineering tissues, organs and cells, J. Tissue Eng. Regen. Med. 1(2), 83-96 (2007).

[18] D. Howard, L.D. Buttery, K.M. Shakesheff, and S.J. Roberts, Tissue engineering: strategies, stem cells and scaffolds, J. Anat. 213(1), 66-72 (2008).

[19] S. Bajada, I. Mazakova, J.B. Richardson, and N. Ashammakhi, Updates on stem cells and their applications in regenerative medicine, J. Tissue Eng. Regen. Med. 2, 169-183 (2008).

[20] M. Malinauskas, H. Gilbergs, V. Purlys, A. Žukauskas, M. Rutkauskas, and R. Gadonas, Femtosecond laserinduced two-photon photopolymerization for structuring of micro-optical and photonic devices, SPIE Proc. 7366, 736622 (2009).

[21] M. Malinauskas, V. Purlys, M. Rutkauskas, A. Gaidukevičiūtè, and R. Gadonas, Femtosecond visible light induced two-photon photopolymerization for 3D micro/nanostructuring in photoresists and photopolymers, Lithuanian J. Phys. [submitted].

[22] M. Malinauskas, V. Purlys, M. Rutkauskas, and R. Gadonas, Two-photon polymerization for fabrication of three-dimensional micro- and nanostructures over a large area, SPIE Proc. 7204, 72040C (2009).

[23] A. Ovsianikov, J. Viertl, B. Chichkov, M. Oubaha, B. MacCraith, I. Sakellari, A. Giakoumaki, D. Gray, M. Vamvakaki, M. Farsari, and C. Fotakis, Ultralow shrinkage hybrid photosensitive material for twophoton polymerization microfabrication, ACS Nano 2(11), 2257-2262 (2008).

[24] S. Schlie, A. Ngezahayo, A. Ovsianikov, T. Fabian, H.A. Kolb, H. Haferkamp, and B.N. Chichkov, Threedimensional cell growth on structures fabricated from ORMOCER by two-photon polymerization technique, J. Biomater. Appl. 22(3), 275-278 (2007).

[25] L. Almany and D. Seliktar, Biosynthetic hydrogel scaffolds made from fibrinogen and polyethylene glycol for 3D cell cultures, Biomater. 26, 2467-2477 (2005). 
[26] R. Širmenis, V. Bukelskienè, V. Domkus, and V. Sirvydis, Cellular cardiomyoplasty: Isolation and cultivation of skeletal muscle satellite cells, Acta Med. Lituanica 6, 178-181 (1999).

[27] R.J. DeVoe, H. Kalweit, C.A. Leatherdale, and C.R. Williams, Voxel shapes in two-photon microfabrication, SPIE Proc. 4797, 310-316 (2003).

[28] S. Inoue and R. Oldenbourg in: Handbook of Optics: Devices, Measurements, and Properties, Vol. 2, ed. M. Bass (McGraw-Hill, 1995) pp. 566-568.

[29] Y. Liu, L. Pyrak-Nolte, and D. Nolte, General 3D microporous structures fabricated with two-photon laser machining, SPIE Proc. 6886, 68860Y (2008).

[30] D. Wu, N. Fang, C. Sun, and X. Zhang, Stiction problems in releasing of 3D microstructures and its solution, Sensors Actuators A 128, 109-115 (2006).

[31] S.H. Park, K.H. Kim, T.W. Lim, D.Y. Yang, and K.S. Lee, Investigation of three-dimensional pattern collapse owing to surface tension using an imperfection finite element model, Microelectron. Eng. 85, 432-439 (2008).

[32] H. Segawa, S. Yamaguchi, Y. Yamazaki, T. Yano,
S. Shibata, and H. Misawa, Top-gathering pillar array of hybrid organic-inorganic material by means of selforganization, Appl. Phys. A 83, 447-451 (2006).

[33] J.C. Chachques, J.C. Trainini, N. Lago, M. CortesMorichetti, O. Schussler, and A. Carpentier, Myocardial assistance by grafting a new bioartificial upgraded myocardium magnum trial: Clinical feasibility study, Ann. Thorac. Surg. 85, 901-908 (2008).

[34] J. Weng and M. Wang, Producing chitin scaffolds with controlled pore size and interconnectivity for tissue engineering, J. Mater. Sci. Lett. 20, 1401-1403 (2001).

[35] S.J. Hollister, R.D. Maddox, and J.M. Taboas, Optimal design and fabrication of scaffolds to mimic tissue properties and satisfy biological constraints, Biomater. 23, 4095-4103 (2002).

[36] D.E. Ingber, Cellular mechanotransduction: putting all the pieces together again, Faseb J. 20, 811-827 (2006).

[37] K. Kaladhar and C.P. Sharma, Surface passivation and controlled ligand supplementation of cellular activation processes - strategies for bottom up synthesis of bioactive surfaces, Trends Biomater. Artif. Organs 21, 29-62 (2007).

\title{
TRIMAČIŲ DIRBTINIŲ POLIMERINIŲ KARKASŲ KAMIENINĖMS LĄSTELĖMS AUGINTI FORMAVIMAS FEMTOSEKUNDINIU LAZERIU
}

\author{
M. Malinauskas ${ }^{\mathrm{a}}$, P. Danilevičius ${ }^{\mathrm{a}}$, D. Baltriukiené ${ }^{\mathrm{b}}$, M. Rutkauskas $^{\mathrm{a}}$, A. Žukauskas ${ }^{\mathrm{a}}$, Ž. Kairyté $^{\mathrm{b}}$, \\ G. Bičkauskaitéa ${ }^{\mathrm{a}}$, V. Purlys ${ }^{\mathrm{a}}$, D. Paipulas ${ }^{\mathrm{a}}$, V. Bukelskiené $\dot{\mathrm{b}}^{\mathrm{b}}$, R. Gadonas ${ }^{\mathrm{a}}$.

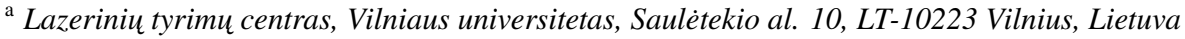 \\ ${ }^{\mathrm{b}}$ Biochemijos instituto vivariumas, Mokslininku 12, LT-08662 Vilnius, Lietuva
}

\section{Santrauka}

Eksperimentiniame darbe pristatomas dirbtinių trimačiu polimerinių karkasų, skirtų kamieninėms ląstelèms auginti, formavimo būdas, naudojant femtosekundinio lazerio šviesa indukuotą polimerizacijos reakciją. Tyrimui naudojamos naujos, perspektyvios medžiagos AKRE37 ir SZ2080. Auginant triušio kamienines ląsteles, tikrinamas šių medžiagų biologinis sutaikomumas ir lyginamas su biomedicinos praktikoje plačiai naudojamomis šviesai jautriomis medžiagomis Ormocore b59 ir PEG-DA-258. Pateikiami for- mavimo erdvinės skyros vertinimai ir trimačių karkasų pavyzdžiai, atskleidžiantys šios technologijos lankstumą ir taikymo galimybes gaminant sudètingos geometrijos mikroporètus karkasus. Lastelių augimo tyrimai rodo, kad medžiagos ir iš jų suformuotu karkasų sandara yra tinkamos biomedicininiams taikymams. Tai - pirmieji žingsniai, kuriant dirbtinius karkasus pažeistiems audiniams atstatyti. Darbe pateiktu būdu jie galètų būti gaminami individualiai kiekvienam pacientui. 